Nama : Muthia Zhafirah Ali

NIM : 90100118037

Kelas : Ekonomi Islam A

\title{
Konsep Ekonomi Islam pada Masa Rasulullah SAW.
}

Umat Islam yakin bahwa Allah SWT menciptakan langit dan bumi untuk kesejahteraan umat manusia. Kesejahteraan dalam ekonomi Islam merupakan terpenuhinya kebutuhan di dunia dan di akhirat yang berdasarkan kebutuhan pribadi dan masyarakat untuk sadar terhadap hukum yang telah dikehendaki oleh Allah SWT melalui Al-Qur'an dan dicontohkan oleh Rasulullah SAW. Seperti yang kita ketahui bahwa ekonomi Islam merupakan konsekuensi yang logis dari kesempurnaan Islam dan harus dipeluk dengan cara kaffah. Disisi lain, ekonomi Islam juga menuntut para pengikutnya untuk professional yang memadai sikap rapi, teratur, benar dan tertib. Oleh karena itu, sebagai umat Islam wajib melaksanakan sesuai dengan yang dilaksanakan oleh Rasulullah SAW pada zamannya. (Fattach, 2018)

Konsep ekonomi Islam pada zaman Rasulullah SAW ditandai dengan Allah SWT menghadirkan Rasulullah SAW di Mekah agar memperbaiki kondisi perekonomian disana. Akan tetapi, Rasulullah SAW tidak mempraktikkan konsep ekonomi Islam di Mekah melainkan di Madinah. Dan praktik ekonomi Islam dilakukan pada zaman Rasulullah SAW dan dilanjutkan oleh umat Islam setelahnya hingga saat ini. Pada saat itu, hampir seluruh umat Islam di Madinah menerima kedatangan Rasulullah SAW yang dilakukan oleh Rasulullah SAW pertama-tama yakni:

1. Membangun masjid yang dijadikan sebagi pembelajaran bagi orang-orang dan digunakan sebagai sarana ibadah.

2. Menyatukan kaum Muhajirin dan Anshar dengan ukhuwah yang dimana orang-orang yang hijrah pada saat itu diakrabkan agar bisa membangun perekonomian lebih baik.

3. Membuat konstitusi negara dengan adanya piagam Madinah sebagai dasar dalam membangun tatanan negara. 
4. Meletakkan dasar-dasar keuangan negara sebagai dasar bermuamalah dan diiringi dengan wahyu.

5. Mengalurkan hak dan kewajiban bagi warga negara untuk menerima dan meberikan sesuatu oleh negara.

6. Menjalin kedamaian dalam negara karena tanpa kedamaian bangunan politik, sosial, ekonomi sulit terjalin sehingga pada saat itu juga Rasulullah SAW kesulitan.

Rasulullah SAW menjalankan konsep ekonomi Islam dengan kebijakan fiskal berlandaskan kepada Al-Qur'an dan Hadits. Yang dimana Al-Qur'an terdiri atas ayat-ayat yang diturunkan secara berangsur-angsur. Pada zaman kepemimpinannya, Rasulullah SAW telah menggali minat dan bakat generasi muda untuk melayani masyarakat agar menghasilkan output untuk kemaslahatan secara positif di kehidupan global dan menghapuska kezaliman dan perbudakan. Perhatian Rasulullah SAW pada saat itu fokus kepada usaha generasi muda untuk menyatukan pengembangan energi yang dimiliki dengan sarana sumber daya yang ada. Langkah awal yang dilakukan Rasulullah SAW setelah diturunkannya ayat Al-Qur'an yakni memulai kebijakan ekonomi. Harta utama yang dimasukkan ke dalam Baitul Mal yakni Khadijah dan Abu Bakar As-Shiddiq yang digunakan untuk membelanjakan kepentingan kemaslahatan umat Islam. Disamping itu, kewajiban zakat dan berbagai cara yang dilakukan untuk memenuhi kemaslahatan umat misalnya Fa'i, Kharaj, Zakat Mal, Ghanimah, Wakaf, Sedekah, Usyur dan Jizyah.

Islam tidak menganggap bahwa kelangkaan sumber daya alam akan menjadi suatu permasalahan seperti yang diterapkan di konsep ekonomi Kapitalis. Akan tetapi permasalahannya terletak pada manusia itu sendiri. Yang dimaksud adalah umat yang tidak bertanggung jawab dan bijak untuk mengelola dan mengembangkan sumber daya yang ada akhirnya terjadilah kerusakan. Metode yang digunakan oleh Rasulullah SAW pada zamannya berkenaan dengan nilai-nilai yang mengandung agama dan fokus pada generasi muda serta mempercayakan kepada para sahabat Rasulullah SAW dalam pembangunan dan perencanaan untuk saling memperkuat antar sesama di zaman Rasulullah SAW (Kharidatul Mudhiiah, 2015) karena agama Islam merupakan agama yang penyempurna dari agama-agama sebelumnya dan selalu berlandas kepada Al-Qur'an dan Hadits. (Kamiruddin, 2018) 


\section{DAFTAR PUSTAKA}

Fattach, A. (2018). Distribusi Pendapatan Kesejahteraan Menurut Konsep Ekonomi Islam. Jurnal Manajemen, 3(2), 728. https://doi.org/10.30736/jpim.v3i2.179

Kharidatul Mudhiiah. (2015). Analisis Sejarah Pemikiran Ekonomi Islam Masa Klasik. Iqthishadia, 8(2), 189-210.

Parakkasi, I., \& Kamiruddin, K. (2018). Analisis Harga Dan Mekanisme Pasar Dalam Perspektif Islam. LAA MAISYIR : Jurnal Ekonomi Islam, 5(1), 107-120. 